\title{
Gedunin- and Khivorin-Derivatives Are Small-Molecule Partial Agonists for Adhesion G Protein-Coupled Receptors GPR56/ADGRG1 and GPR114/ADGRG5 $\$$
}

\author{
Hannah M. Stoveken, Scott D. Larsen, Alan V. Smrcka, and Gregory G. Tall \\ Departments of Pharmacology (H.M.S., A.V.S., G.G.T.) and Medicinal Chemistry (S.D.L.), University of Michigan, \\ Ann Arbor, Michigan
}

Received December 19, 2017; accepted February 22, 2018

\begin{abstract}
Adhesion G protein-coupled receptors (aGPCRs) have emerged as potential therapeutic targets in multiple cancers and in neurologic diseases. However, there are few modulatory compounds that act on these receptors. The majority of aGPCRs are orphans and a general activation mechanism has only recently been defined: aGPCRs are activated by a tethered agonist. aGPCRs constitutively cleave themselves during biosynthesis to generated two-part receptors comprising an extracellular domain (ECD) and a 7-transmembrane spanning domain (7TM). ECD dissociation reveals the tethered agonist initiating $\mathrm{G}$ protein signaling. Synthetic peptides that mimic the tethered agonist region can activate aGPCRs. We hypothesized that small molecules could act in the same way as peptide agonists. High throughput screening of the 2000-compound Spectrum Collection library using the serum response element luciferase gene
\end{abstract}

reporter assay revealed two related classes of small molecules that could activate the aGPCR GPR56/ADGRG1. The most potent compound identified was 3- $\alpha$-acetoxydihydrodeoxygedunin, or 3- $\alpha$-DOG. 3- $\alpha$-DOG activated engineered, low-activity GPR56 7TM in independent biochemical and cell-based assays with an $\mathrm{EC}_{50}$ of $\sim 5 \mu \mathrm{M}$. The compound also activated a subset of aGPCRs but not two class A GPCRs tested. The mode of 3- $\alpha$-DOG-mediated receptor activation is that of partial agonist. 3- $\alpha-D O G$ activated GPR56 less efficaciously than peptide agonist and could antagonize both the peptide agonist and the endogenous tethered agonist, which are pharmacological hallmarks of partial agonists. Taken together, we have uncovered a novel group of aGPCR partial agonists that will serve as invaluable resources for understanding this unique class receptors.

\section{Introduction}

Few modulatory compounds have been identified for the class of adhesion G protein-coupled receptors (aGPCRs) (Gupte et al., 2012; Hamann et al., 2015; Stoveken et al., 2016). These 33 receptors comprise $\sim 10 \%$ of nonsensory GPCRs and have critical roles in organogenesis, immune cell function, surfactant homeostasis, synapse function, and much more (Yona et al., 2008b; Bridges et al., 2013; Langenhan et al., 2013; Hamann et al., 2015). In addition, aGPCRs are the most frequently mutated GPCR subclass in cancers and may contribute to tumor growth, migration, invasion, and metastasis (Aust, 2010; O'Hayre et al., 2013; Aust et al., 2016). The transcript levels of $>50 \%$ of aGPCRs are altered in various cancers compared with normal tissues (Aust, 2010; Aust et al., 2016). Despite the relevance of aGPCRs to human physiology and disease, the number of modulatory compounds that might be used to probe aGPCR biology and/or be used as potential

This work was supported by the National Institutes of Health National Institute of General Medical Sciences [GM120110, GM088242] to G.G.T

https://doi.org/10.1124/mol.117.111476.

S This article has supplemental material available at molpharm. aspetjournals.org. therapeutic leads is very low. Identifying modulatory compounds has been challenging owing to the distinctive pharmacology of aGPCRs: The receptors are self-activated by tethered-peptide-agonists (Liebscher et al., 2014; Stoveken et al., 2015). Unlike the prototypical tethered-peptideagonist-activated GPCRs, the (exogenous) protease-activated receptors, adhesion GPCR tethered-peptide-agonists are generated by receptor self-cleavage within the extracellular, membrane-proximal GPCR autoproteolysis-inducing (GAIN) domains (Lin et al., 2004; Arac et al., 2012). Self-cleavage produces two-fragment receptors composed of noncovalently bound variable extracellular domains (ECDs) or amino-terminal fragments (NTFs) and 7-transmembrane spanning domains (7TMs) (Lin et al., 2004; Arac et al., 2012). Our work recently helped define a general mechanism of aGPCR activation whereby constitutive self-proteolysis at the defined, GAIN domain cleavage site generates the tethered-peptide-agonist, which remains concealed within the core of the GAIN domain of inactive-state aGPCRs (Liebscher et al., 2014; Stoveken et al., 2015). We demonstrated that biochemical dissociation of aGPCR extracellular and 7TM domains revealed the tetheredpeptide-agonist and permitted binding to its presumed orthosteric site to activate signaling. However, the physiologic

ABBREVIATIONS: aGPCR, adhesion G protein-coupled receptor; DHM, dihydromunduletone; DMEM, Dulbecco's modified Eagle's medium; DMSO, dimethylsulfoxide; 3- $\alpha$-DOG, 3- $\alpha$-acetoxydihydrodeoxygedunin; ECD, extracellular domain; ECM, extracellular matrix; FBS, fetal bovine serum; GAIN, GPCR autoproteolysis-inducing domain; GPCR, G protein-coupled receptor; HTS, high-throughput screening; NTF, amino-terminal fragment; PEI, polyethylenimine; SRE, serum response element; 7TM, seven-transmembrane spanning domain. 
mechanism that reveals the tethered-peptide-agonist and the identity of the orthosteric binding site are unknown and subjects of active investigation.

The identified ligands for aGPCRs consist of two general subtypes. One set of proteins emanate from the surfaces of neighboring cells and span extracellular space to bind adhesion modules of aGPCR extracellular domains. Prominent examples are often synaptic and include, brain angiogenesis inhibitors-1, -2, and -3 (BAI1-3, or ADGRB1-3), Latrophilin$1,-2$, and -3 (LPHN-1-3, or ADGRL1-3), and the immune GPCR CD97 (ADGRE5) (Hamann et al., 1996; Bolliger et al., 2011; Silva et al., 2011; O'Sullivan et al., 2012; Stephenson et al., 2014). The second type of ligands are extracellular matrix (ECM) proteins, such as collagens, transglutaminase2, and laminins (Stacey et al., 2003; Vallon and Essler, 2006; Xu et al., 2006; Luo et al., 2011; Paavola et al., 2014; Petersen et al., 2015). We favor a hypothesis that both types of aGPCR ligands facilitate signaling by acting as anchors that affix aGPCR extracellular domains. Cell-mediated shear force then dissociates the two aGPCR fragments to release the tetheredpeptide-agonist from its concealed location so that it may engage its 7TM-domain orthosteric binding site (Karpus et al., 2013; Langenhan et al., 2013; Scholz et al., 2015; Stoveken et al., 2015).

Experimentally simulating the cell and ECM microenvironment to demonstrate aGPCR fragment dissociation that is concomitant with tethered-peptide agonist-mediated G protein activation has proven to be a great technical challenge. It may also not be feasible to develop aGPCR pharmacological modulators on the basis of this proposed two-step activation process. As such, development of small-molecule modulatory compounds that directly activate aGPCRs will be critical to probe the function of these receptors and perhaps be developed as future therapeutic lead compounds.

A few small molecules and engineered antibodies have been suggested to activate individual adhesion GPCRs. Smallmolecule GPR97/ADGRG3 potential activators were identified in high-throughput screens by two groups (Gupte et al., 2012; Southern et al., 2013). Synaptamide, a metabolite of the omega-3 fatty acid docosahexaenoic acid, was reported to bind the extracellular domain of GPR110/ADGRF1 and increase cellular cAMP independent of GPR110 tethered agonism (Lee et al., 2016). However, GPR110 did not activate Gs in our biochemical reconstitution assays, but activated Gq in response to its tethered agonist (Stoveken et al., 2015). Antibodies raised against the ECDs of CD97/ADGRE5, EMR2/ADGRE2, and GPR56/ADGRG1 have been reported to modulate activities of these receptors (Iguchi et al., 2008; Veninga et al., 2008; Yona et al., 2008a; de Groot et al., 2009). Finally, we identified a small-molecule neutral antagonist, dihydromunduletone, that inhibits GPR56 and GPR56related adhesion GPCRs (Stoveken et al., 2016).

Here we conducted high-throughput screening (HTS) of a chemical library to identify small-molecule modulatory compounds that activate GPR56 independent of its tetheredpeptide-agonist. A luciferase gene reporter HTS assay was developed on the basis of an engineered GPR56/ADGRG1 7TM receptor in which a portion of the tethered-peptide-agonist was truncated and therefore had markedly reduced activity that could be stimulated by a synthetic peptide agonist (Stoveken et al., 2015). This model of low or basal receptor activity was adapted for a cell-based HTS assay and used to screen the $\sim 2000$ compound Spectrum Collection chemical library (Microsource Discovery Systems, Gaylordsville, CT). Two classes of related compounds, gedunin- and khivorinderived natural products, were identified by HTS that activated tethered-peptide agonist-deficient GPR56 in secondary, independent biochemical reconstitution assays and other orthogonal cell-based assays. Structure-activity relationship analyses of additional gedunin and khivorin-derived compounds identified two critical acetoxy functional groups responsible for the bioactivity and potency of these natural products. Activation of the basally active GPR56-A386M 7TM receptor by the lead gedunin-derived compound $3-\alpha$-acetoxydihydrodeoxygedunin, (or $3-\alpha$-DOG for brevity) was less efficacious but more potent than the synthetic peptide agonist. $3-\alpha$-DOG was inhibited by the aGPCR near-neutral antagonist dihydromunduletone and, at high concentrations, 3- $\alpha$-DOG also neutralized (inhibited) higher-efficacy synthetic-peptide agonists. Taken together, our results demonstrate that 3 - $\alpha$-DOG is a first-in-class partial agonist for the class VIII aGPCRs, GPR56 and GPR114.

\section{Materials and Methods}

Reagents and Antibodies. The phRLuc-N1 plasmid, $\left[{ }^{35} \mathrm{~S}\right]$ GTP $\gamma \mathrm{S}$, and the steadylite luciferase reagent used in the serum responses element (SRE)-luciferase high-throughput screening assays were from PerkinElmer (Waltham, MA). GTP $\gamma \mathrm{S}$ was purchased from MilliporeSigma (St. Louis, MO). Rhotekin-BD beads were from Cytoskeleton, Inc. (Denver, CO). Monoclonal anti-HA antibody (clone HA7) was purchased from Sigma-Aldrich. pGL4.33 [luc2/SRE/Hygro] plasmid was purchased from Promega (Madison, WI). 3- $\alpha$-Acetoxydihydrodeoxygedunin, khivorin, deoxygedunin, 1,2-epoxygedunin, 3-deacetylkhivorin, 7-deacetoxy7-oxokhivorin, 7-deacetoxy-7-oxogedunin, and 1,7-dideacetoxy-1,7-dioxo-3deacetylkhivorin were purchased as powders from Microsource Discovery Systems, Inc. Firefly Luc assay reagent for Dual SRE-luciferase assays and coelenterazine $\mathrm{H}$ were from NanoLight Technologies (Pinetop, AZ). GPR110 P12 (TSFSILMSPFVP-NH ${ }_{2}$ ) and GPR56 P7 (TYFAVLM-NH ${ }_{2}$ ) peptides were synthesized at Biomatik (Wilmington, $\mathrm{DE}$ ) and solubilized in dimethylsulfoxide (DMSO) as described (Stoveken et al., 2015).

High-Throughput Screening SRE-Luciferase Assay. Compounds in DMSO from the Spectrum Collection (Microsource Discovery Systems, Inc.), or positive-control fetal bovine serum (FBS; Gibco/Thermo Fisher Scientific, Gaithersburg, MD) were robotically pipetted into $5 \mu \mathrm{l}$ of serum-free, phenol red-free Dulbecco's modified Eagle's medium (DMEM) buffered with 25 mM Hepes, pH 7.4, in 384well plates. The final concentration of compounds was $3-5 \mu \mathrm{M}$, and DMSO did not exceed a final concentration of $0.5 \% \mathrm{v} / \mathrm{v}$.

HEK293T cells were seeded at $4 \times 10^{6}$ cells in $10-\mathrm{cm}$ dishes in DMEM $+10 \% \mathrm{v} / \mathrm{v}$ FBS 24 hours prior to transfection. For each dish, $6.5 \mu \mathrm{g}$ of pcDNA3.1(+), GPR56 7TM (Met-T383-I687), or GPR56-A386M 7TM (M386-I687) in pcDNA3.1 and $3.2 \mu \mathrm{g}$ of the SREluciferase plasmid, pGL4.33 were transfected using a polyethylenimine (PEI) transfection method (Oner et al., 2013; Stoveken et al., 2015). The transfection proceeded for 5-7 hours. The transfected cells were then trypsinized, pooled, washed with DMEM. Fifteen-thousand cells in $15 \mu \mathrm{l}$ of serum-free, phenol red-free DMEM buffered with $25 \mathrm{mM}$ Hepes, $\mathrm{pH} 7.4$, were seeded into the 384-well plates that had been prefilled with compounds/controls. The incubation with compounds proceeded for 18 hours at $37^{\circ} \mathrm{C}$ in a humidified incubator and $5 \% \mathrm{CO}_{2}$ atmosphere. An equivalent volume $(20 \mu \mathrm{l})$ of steadylite reagent (PerkinElmer) was robotically delivered to each well and incubated for 15 minutes at $22^{\circ} \mathrm{C}$. Raw luminescence values were attained using a PerkinElmer Envision Plate reader.

For optimization trials of the high-throughput screen (HTS) SREluciferase assay, cells were transfected as above and treated with 
DMSO or P7 (TYFAVLM-NH ${ }_{2}$ ) synthetic peptide agonist for 18-24 hours. Luminescence was read 15 minutes after an equal volume addition of steadylite luciferase reagent using a Berthold Technologies TriStar ${ }^{2}$ LB 942 plate reader (Bad Wildbad, Germany).

Dual Luciferase Assays. HEK293T cells were plated at $2 \times 10^{5}$ cells per well in DMEM + 10\% (v/v) FBS in 24-well dishes coated with $0.1 \% \mathrm{v} / \mathrm{v}$ gelatin. Twenty-four hours later, cells were transiently transfected using the PEI method with $25 \mathrm{ng}$ of adhesion GPCR pcDNA3.1 plasmid, $100 \mathrm{ng}$ of SRE-luciferase reporter (pGL4.33), and $1 \mathrm{ng}$ of phRLucN-1 or luciferase reporters alone (Stoveken et al., 2015). DNA levels were balanced among transfections by addition of pcDNA3.1 to $450 \mathrm{ng}$ total DNA. After 18 hours, cells were serumstarved for 9-10 hours in serum-free DMEM. The indicated compounds or synthetic peptide agonist P7 was added twice to the medium at 6 and 4 hours prior to luminescence readings to yield the final concentration indicated in each experiment. Final DMSO concentration did not exceed $1 \%$ of total volume. Cells were washed in Tyrode's buffer $\left(137 \mathrm{mM} \mathrm{NaCl}, 2.7 \mathrm{mM} \mathrm{KCl}, 1 \mathrm{mM} \mathrm{MgCl} 2,1.8 \mathrm{mM} \mathrm{CaCl}_{2}\right.$, $0.2 \mathrm{mM}, \mathrm{Na}_{2} \mathrm{HPO}_{4}, 12 \mathrm{mM} \mathrm{NaHCO} 3,5.5 \mathrm{mM}$ D-glucose), lysed in Firefly Luciferase (FLuc) Assay Reagent (NanoLight Technologies), and luminescence was measured as described (Stoveken et al., 2016). An equal volume of Renilla luciferase (RLuc) quench buffer containing $3 \mu \mathrm{M}$ coelenterazine $\mathrm{H}$ was added to each well (Dyer et al., 2000). All FLuc readings were normalized to the RLuc signal and expressed as fold-increase over cells transfected with the luciferase reporters alone.

Baculovirus Generation and Insect Cell Culture. Spodoptera frugiperda 9 (Sf9) and Trichoplusia ni (High Five) insect cells were cultured in IPL-41 medium (Invitrogen, Waltham, MA) containing $10 \% \mathrm{v} / \mathrm{v}$ heat-inactivated FBS or Sf900II medium as described (Stoveken et al., 2015). Recombinant GPCR baculoviruses were generated from pFastBac-1 baculoviral donor plasmids using the Bac-to-Bac system according to the manufacturer's specifications (Invitrogen/Thermo Fisher Scientific). Recombinant GPCR baculoviruses were amplified once or twice for 72-96 hours in mid-log-phase $S f 9$ cells, and a 1:50 or 1:100 dilution of the viral supernatants, respectively, was used to infect High ,Five suspension cells for 48-hour periods of GPCR expression. High Five cells from 50 to $200 \mathrm{ml}$ of culture were harvested from the medium by centrifugation at $1000 \mathrm{~g}$ and stored as a frozen cell paste at $-80^{\circ} \mathrm{C}$ or used fresh to prepare adhesion GPCR membranes.

GPCR/G Protein Reconstitution Assays. Recombinant G $\alpha 13$ and $\mathrm{G} \alpha \mathrm{q}$ were purified by association with GST-Ric- $8 \mathrm{~A}$ and recombinant $\mathrm{G} \alpha$ s was purified by association with GST-Ric-8B as described (Chan et al., 2011). Recombinant $\mathrm{G} \beta_{1} \gamma_{2}$ was purified from High Five insect cell membranes by association with $\mathrm{G} \alpha \mathrm{i}_{1}-\mathrm{His}_{6}$ (Kozasa and Gilman, 1995).

GPCR membranes were prepared by lysing High Five cells in $20 \mathrm{mM}$ Hepes, $\mathrm{pH}$ 7.4, $1 \mathrm{mM}$ EGTA, and protease inhibitor cocktail $(23 \mu \mathrm{g} / \mathrm{ml}$ phenylmethylsulfonyl fluoride, $21 \mu \mathrm{g} / \mathrm{ml} \mathrm{N}$ - $p$-tosyl-L-lysinechloromethyl ketone, $21 \mu \mathrm{g} / \mathrm{ml} \quad L$-1-p-tosylamino-2-phenylethylchloroketone, $3.3 \mu \mathrm{g} / \mathrm{ml}$ leupeptin, and $3.3 \mu \mathrm{g} / \mathrm{ml}$ lima bean trypsin inhibitor) using a nitrogen cavitation disruption vessel (Parr Instruments, Moline, IL). The cell lysates were centrifuged at $1500 \mathrm{~g}$ to clear debris, and the supernatant was centrifuged at 100,000g to pellet cell membranes. The membranes were washed by Dounce homogenization into lysis buffer and then recentrifuged. Washed membranes with intact adhesion GPCRs (ECD + 7TM domain) were Douncehomogenized into storage buffer (20 mM Hepes, pH 7.4, 1 mM EGTA, $12 \%$ v/v sucrose) (Stoveken et al., 2015). Membranes with class A GPCRs or tethered-peptide-agonist-activated adhesion GPCRs were treated with ice-cold $8 \mathrm{M}$ urea to remove endogenous $\mathrm{G}$ proteins and to dissociate and solubilize the noncovalently bound adhesion GPCR ECDs. The urea-insoluble membranes (containing the 7TM domains) were washed extensively and resuspended in membrane storage buffer by Dounce homogenization. The total protein concentration of each membrane preparation was determined by Bradford protein assay.

Five micrograms of intact adhesion GPCR membranes, an equivalent volume of urea-treated membranes, or $1 \mu \mathrm{g}$ of urea-treated membranes for engineered adhesion GPCR 7TM receptors or class A GPCRs were reconstituted with $100 \mathrm{nM}$ purified $\mathrm{G} \alpha$ protein and $500 \mathrm{nM} \mathrm{G} \beta_{1} \gamma_{2}$ in $20 \mathrm{mM}$ Hepes, $100 \mathrm{mM} \mathrm{NaCl}, 1 \mathrm{mM}$ dithiothreitol, 0 or $20 \mu \mathrm{M}$ GDP, $1 \mathrm{mM}$ EDTA, and $3 \mu \mathrm{g} / \mathrm{ml}$ bovine serum albumin. Receptor membranes and $\mathrm{G}$ proteins were preincubated for 30 minutes with compounds, synthetic peptide agonists, or DMSO vehicle control. Kinetic G protein GTP $\gamma \mathrm{S}$ binding assays were initiated by the addition of $2 \mu \mathrm{M}\left[{ }^{35} \mathrm{~S}\right] \mathrm{GTP} \gamma \mathrm{S}(10-50,000 \mathrm{cpm} / \mathrm{pmol}), 5 \mathrm{mM} \mathrm{MgCl}_{2}$, and $25 \mathrm{mM}$ $\mathrm{NaCl}$. Measurement of $\mathrm{G}$ protein $\left[{ }^{35} \mathrm{~S}\right] \mathrm{GTP} \gamma \mathrm{S}$ binding was made via a nitrocellulose filter binding method as described (Stoveken et al., 2016). For the concentration-response analyses, the initial rates of $\mathrm{G}$ protein GTP $\gamma \mathrm{S}$ binding were measured in triplicate at 1,2 , and 3 minutes.

Rho Activation Assay. HEK293T cells were seeded at $3.5 \times 10^{6}$ cells on 10 -cm plates 24 hours prior to transfection in DMEM $+10 \%$ (v/v) FBS. One microgram of HA-tagged RhoA (cDNA.org) and 1-2 $\mu \mathrm{g}$ GPR56-A386M 7TM receptor (M386-I687) in pcDNA3.1 were transfected using the PEI transfection method (Oner et al., 2013; Stoveken et al., 2015). Transfection proceeded for 5-8 hours when cells were washed and incubated with DMEM without FBS for 18 hours. Either $2.5 \mu \mathrm{M} 3-\alpha$-DOG, $10 \mu \mathrm{M}$ P7 (TYFAVLM), or DMSO was supplemented into the medium of each $10-\mathrm{cm}$ plate in a total volume of $20 \mu \mathrm{l}$ and incubated at $37^{\circ} \mathrm{C}$ for $2-10$ minutes. Adherent cells were gently washed with phosphate-buffered saline (PBS) containing protease inhibitor cocktail and lysed in $1 \mathrm{ml}$ of $25 \mathrm{mM}$ Tris-HCl, $\mathrm{pH} 7.2,150 \mathrm{mM}$ $\mathrm{NaCl}, 5 \mathrm{mM} \mathrm{MgCl} 2,1 \% \mathrm{NP}-40,5 \%$ glycerol, and protease inhibitor cocktail. As a positive control, the lysate from DMSO-treated cells was incubated with $50 \mu \mathrm{M}$ GTP $\gamma \mathrm{S}$. Equivalent amounts of cell lysate were incubated with $60 \mu \mathrm{g}$ of GST-Rhotekin-binding domain (GST-RBD)conjugated glutathione agarose (Cytoskeleton, Inc.) for 75 minutes, the resin was washed three times with lysis buffer, and proteins were eluted in $60 \mu \mathrm{l}$ of $2 \times$ sample buffer ( $200 \mathrm{mM}$ Tris, $\mathrm{pH} 6.8,20 \%$ glycerol, $4 \%$ SDS, $200 \mathrm{mM}$ dithiothreitol, $0.02 \%$ bromophenol blue) (Laemmli, 1970). Cell lysates were normalized by determining the amount of total protein in each lysate using the amido black protein assay (Schaffner and Weissmann, 1973). HA-tagged RhoA was detected by Western blotting with monoclonal anti-HA antibody (MilliporeSigma).

Statistics. All statistical tests were performed using GraphPad Prism 7 (San Diego, CA). Unless explicitly noted, error bars represent S.D. of the mean. Unpaired student's $t$ tests were used to compare the significance of $G$ protein-reconstitution-assay kinetic data of receptors treated with $3-\alpha$-DOG to controls at early time points $(2,5$ and 10 minutes). Comparisons between groups treated with DMSO or with compounds (peptides or small-molecule natural products) in the directed luciferase gene reporter assays were compared using unpaired, two-tailed Student's $t$ tests.

\section{Results}

High-Throughput Screening for the Identification of Small-Molecule GPR56 Activators. Adhesion GPCRs are activated via a tethered-peptide-agonist mechanism (Liebscher et al., 2014; Stoveken et al., 2015). On the basis of this activation paradigm, we engineered a series of adhesion GPCR 7TM domains with successive deletion of the $\mathrm{N}$-terminal amino acids that comprise the tethered agonists. The result was the creation of a spectrum of receptor activity states spanning the range of full tethered agonism to models of low basal receptor activity (no tethered agonism) (Stoveken et al., 2015). We recently conducted an HTS to attain smallmolecule inhibitors of full-agonist-activated GPR56 and uncovered the first characterized adhesion GPCR smallmolecule antagonist, dihydromunduletone (Stoveken et al., 2016). Here, compounds were sought that could stimulate basally active GPR56. GPR56-A386M 7TM lacks the NTF/ECD and the first three amino acids of the tethered 
A GPR56 7TM Constructs:

7TM:

A386M 7TM:

Synthetic Agonist Peptide ("P7"):
MTYFAVLMVSSVEVDAVHKHYLLS-TM1 MVLMVSSVEVDAVHKHYLLS-TM1 TYFAVLM

\section{B}

$$
\text { GPR56 7TMs with Truncated Tethered-Peptide Agonists } \pm \text { P7 }
$$

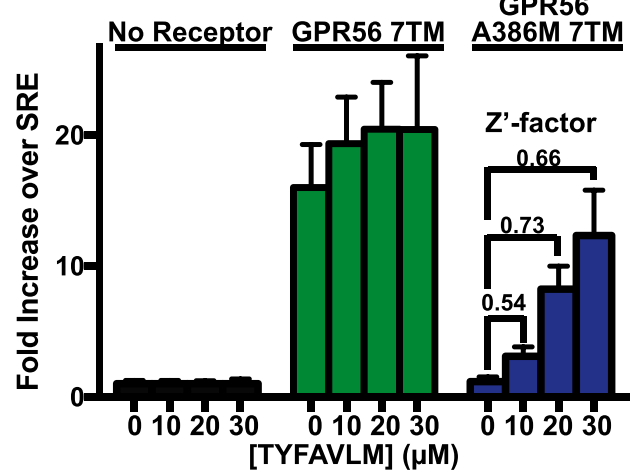

C

Compromised Tethered Agonist GPR56 A386M 7TM Activator Screen
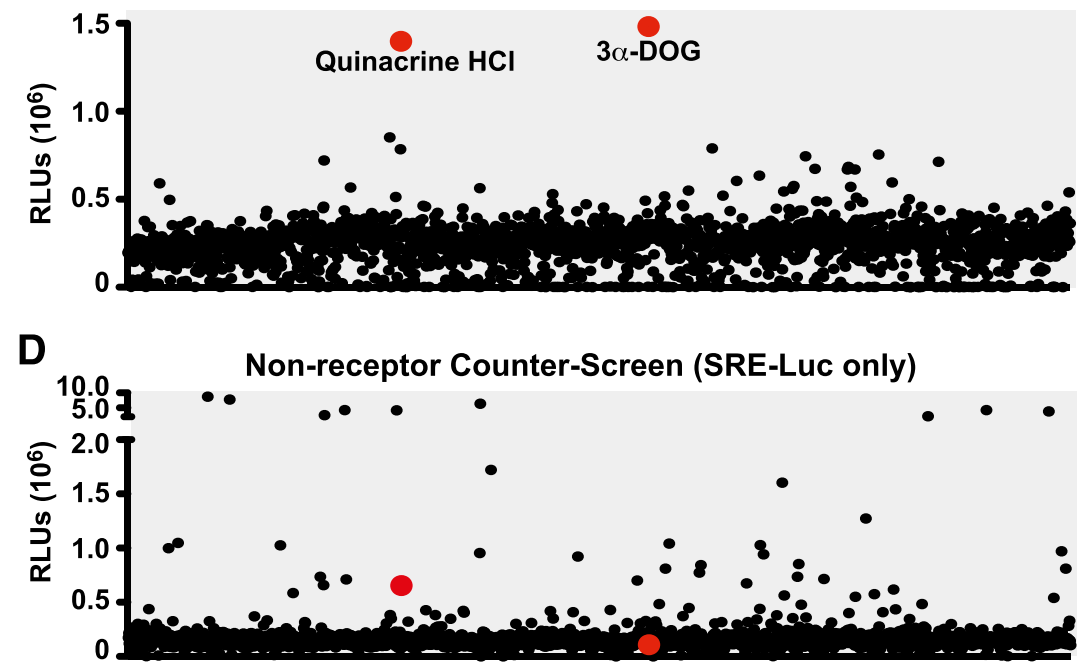

Fig. 1. High-throughput screen and counter-screen for activators of compromised tethered-peptide-agonist GPR56. (A) Schematic of the tethered agonist region of GPR56 7TM in comparison with the tethered-peptideagonist-compromised GPR56-A386M 7TM receptor and alignment of the GPR56 activating peptide (P7). Artificial initiator methionine placements are shown in red. (B) Optimization of the high-throughput screen was performed in a 384-well plate with increasing concentrations of TYFAVLM (P7) peptide. The data are the mean \pm S.D. of 16 replicates. $\mathrm{Z}^{\prime}$ assay quality scores were calculated for each concentration of TYFAVLM (P7) peptide tested. HEK293T cells transiently transfected with the SREluciferase reporter and the (C) GPR56-A386M 7TM (high-throughput screen) plasmid, or (D) empty vector (high-throughput counter-screen) were seeded into wells containing $\sim 3-5 \mu \mathrm{M}$ DMSO-solubilized compounds from the Spectrum Collection. Luminescence was measured after an 18-hour incubation period. Each point represents one individual compound tested. agonist (N-term: T,Y,F), with the fourth residue, alanine, mutated to the initiator methionine (Fig. 1A). GPR56-A386M 7TM was chosen for the activator HTS owing to its optimized signal-to-noise ratio. It had low basal SRE-Luc activity, yet could be activated $\geq 10$-fold by synthetic peptide agonist (P7) (Fig. 1B). The $\mathrm{Z}^{\prime}$-factors calculated from these data were between 0.5 and 0.73 on the basis of the concentration of synthetic peptide agonist used, which is indicative of a highquality HTS assay (Zhang et al., 1999).

For the activator HTS, compounds were sought that could substitute for synthetic peptide agonist and stimulate the activity of GPR56-A386M 7TM (screen, Fig. 1C) but did not alter the luciferase signal in nonreceptor-expressing cells (counter-screen, Fig. 1D). Attempts to produce cell lines with stable receptors and/or gene reporter expression were successful, but full responsiveness to synthetic peptide agonist was lost, suggestive of remodeling of the signal transduction pathway. Reproducible synthetic peptide agonist activation of SRE-Luc was observed in HEK293T cells transiently transfected with the SRE luciferase reporter and GPR56A386M 7TM pcDNA3.1, so transiently transfected cells were used for the HTS and counter-screen. The 2000-compound
Spectrum Collection of bioactive drugs, derivatives, and natural products was fully screened and counter-screened. Two compounds provided substantial activation in the GPR56-A386M 7TM screen over the SRE-Luc counterscreen: quinacrine- $\mathrm{HCl}$ and 3 - $\alpha$-acetoxydihydrodeoxygedunin (3- $\alpha$-DOG) (Fig. 1, C and D).

Quinacrine was eliminated as a potential receptoractivating compound. In the HTS, quinacrine enhanced luciferase activity of receptor-expressing cells $\sim 2$-fold over nonreceptor cells (Fig. 1C; Supplemental Fig. 1A), but notably, the activity in nonreceptor cells was substantially above background (Fig. 1D; Supplemental Fig. 1A). In a secondary, directed luciferase assay using the compromised tethered agonist GPR56-M389-start 7TM receptor, quinacrine-HCl nonspecifically enhanced the luciferase signal in naïve and receptor-expressing cells (Supplemental Fig. 1B), thereby eliminating it as a receptor-specific hit.

3- $\alpha$-Acetoxydihydrodeoxygedunin (3- $\alpha$-DOG) Enhances G13 Activation and Signaling Pathways Modulated by GPR56. $3-\alpha$-DOG withstood specificity testing, so it was chosen for further characterization. The compound is a steroid-like gedunin-derivative that was isolated from plant 
A Limonoid Skeleton 3- $\alpha$-acetoxydihydrodeoxygedunin<smiles></smiles>

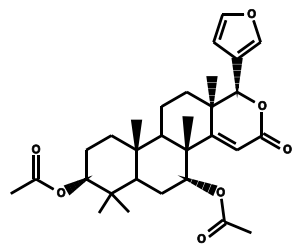

GPR56 7TM Truncation Series $\pm 5 \mu M$ 3- $\alpha$-DOG

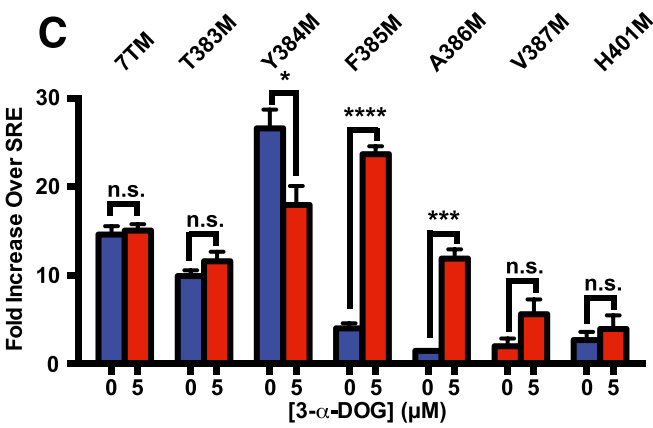

$\mathbf{E}$

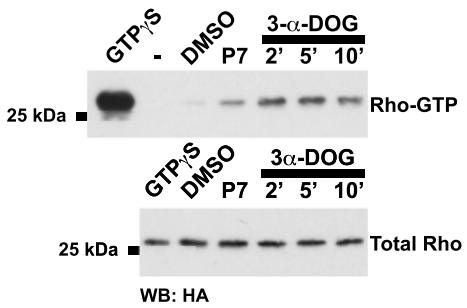

GPR56 7TM Constructs:

7TM:

T383M 7TM:

Y384M 7TM:

F385M 7TM:

A386M 7TM:

V387M 7TM:

H401M 7TM:

Synthetic Agonist Peptide ("P7"):

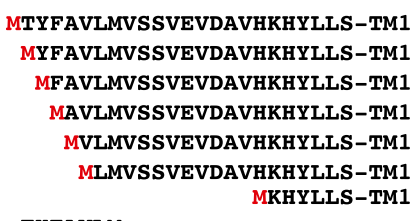

TYFAVLM
GPR56 A386M \& H401M 7TM Low-Activity Receptors $\pm 20 \mu \mathrm{M} 3-\alpha-\mathrm{DOG}$

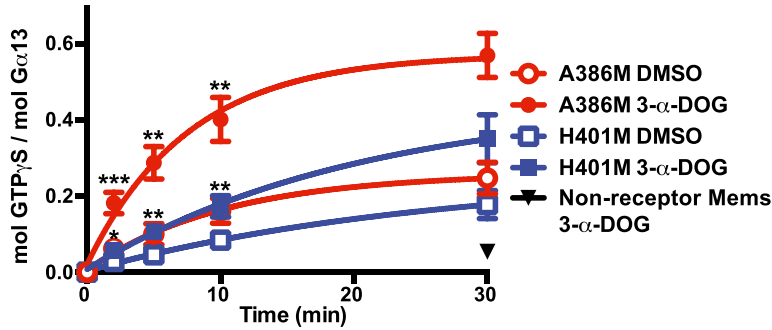

F

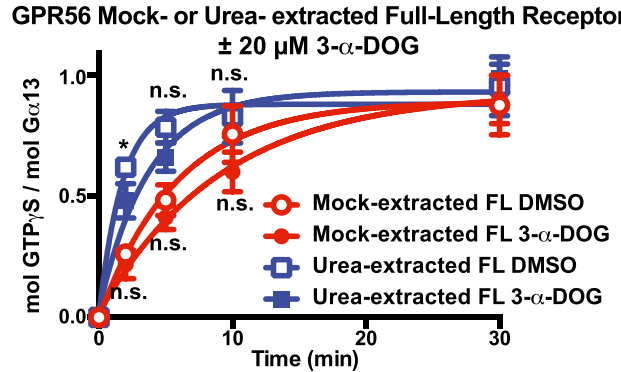

Fig. 2. 3- $\alpha$-Acetoxydihydrodeoxygedunin is a small-molecule activator of GPR56/ADGRG1. (A) Chemical structure of 3- $\alpha$-acetoxydihydrodeoxygedunin (3- $\alpha$-DOG) side-by-side with a generalized skeleton for the limonoid class. (B) Comparison of the tethered-agonist regions of engineered GPR56 7TM receptors. (C) GPR56 7TM receptors with intact (7TM) or truncated tethered-agonist residues were treated with vehicle (blue bars) or with $5 \mu$ M 3 - $\alpha$-DOG (red bars) in an SRE-luciferase gene reporter assay. Data are normalized to Renilla luciferase control and expressed as fold over the signal obtained from cells transfected with SRE-luciferase only. Error bars are the mean \pm S.D. of three biologic replicates with two technical replicates per experiment. (D) GPR56-A386M 7TM (truncated tethered-peptide-agonist) and GPR56-H401M 7TM (no tethered-peptide-agonist) receptor membranes, or control, nonreceptor membranes were reconstituted with purified, recombinant G $\alpha 13$ and G $\beta_{1} \gamma_{2}$. Membranes were preincubated with 3- $\alpha$-DOG or DMSO for 5 minutes. ${ }^{35}$ S $]$ GTP $\gamma$ S binding to G13 was then measured over time. Graphs were fitted to monoexponential functions using GraphPad Prism. Error bars are the mean \pm S.D. of three experimental replicates with two technical replicates per experiment. 3- $\alpha$-DOG-mediated activation of A386M 7TM and H401M was significant compared with control, DMSO-treated receptor $(* P<0.05 ; * * P<0.01 ; * * * P<0.001 ; * * * * P<0.0001)$. (E) RhoA activation by acute treatment of GPR56-A386M 7TM-expressing HEK293T cells with 3- $\alpha$-DOG or P7 synthetic peptide agonist. The Western blot is representative of three independent experiments. (F) Untreated and urea-treated GPR56 full-length membranes were reconstituted with G $\alpha 13$ and G $\beta_{1} \gamma_{2}$ and preincubated with 0 or $20 \mu \mathrm{M} 3$ - $\alpha$-DOG prior to measurement of G13 ${ }^{35}$ S $]$ GTP $\gamma$ S binding kinetics. Error bars are the mean \pm S.D. of three experimental replicates with two to three technical replicates per experiment $\left({ }^{*} P<0.05\right.$; n.s., not significant compared with cells treated with DMSO).

species belonging to the Meliaceae family (Khalid et al., 1989). Gedunins and similar limonoids share a furanolactone core structure (Fig. 2A) (Roy and Saraf, 2006). Some limonoids were purported to demonstrate antimalarial, antibacterial, and anticancer properties (Khalid et al., 1989; MacKinnon et al., 1997; Uddin et al., 2007; Kamath et al., 2009). 3- $\alpha$-DOG was tested for activation of the compromised tethered agonist GPR56-7TM receptor series by SRE-luciferase assay (Fig. 2, B and C). 3- $\alpha$-DOG stimulated GPR56-mediated SRE-luciferase activity of 7TM receptors with two or more N-terminal tethered-agonist amino acids deleted (F385M through V387M). However, $3-\alpha$-DOG did not provide significant activation of the H401M receptor in the SRE-luciferase assay. GPR56-H401M 7TM has the majority of the tethered-peptideagonist-containing stalk truncated (i.e., stalkless). This result aligns with previous results suggesting that multiple components of adhesion GPCR stalks that emanate from TM1 seem to be required for full tethered agonism: a component at the stalk $\mathrm{N}$-terminus, for which $3-\alpha$-DOG might substitute, and a second component proximal to TM1 (Stoveken et al., 2015; Wilde et al., 2016).

$3-\alpha$-DOG was then tested using our independent assay platforms that measure GPCR activation of reconstituted G protein heterotrimers. Membranes prepared from insect cells expressing recombinant GPCRs were reconstituted with purified $G$ protein heterotrimers, and the kinetics of receptor-stimulated $\mathrm{G}$ protein $\left[{ }^{35} \mathrm{~S}\right] \mathrm{GTP} \gamma \mathrm{S}$ binding were measured. Optional membrane pretreatment with $8 \mathrm{M}$ urea reduces endogenous $\mathrm{G}$ protein levels (background signal) and, in the case of full-length adhesion GPCRs, activates the receptors by dissociating the noncovalently bound NTF to reveal the tethered-peptide-agonist (Stoveken et al., 2015). 3 - $\alpha$-DOG $(20 \mu \mathrm{M})$ was briefly preincubated with urea-treated, naïve membranes and membranes that expressed GPR56- 

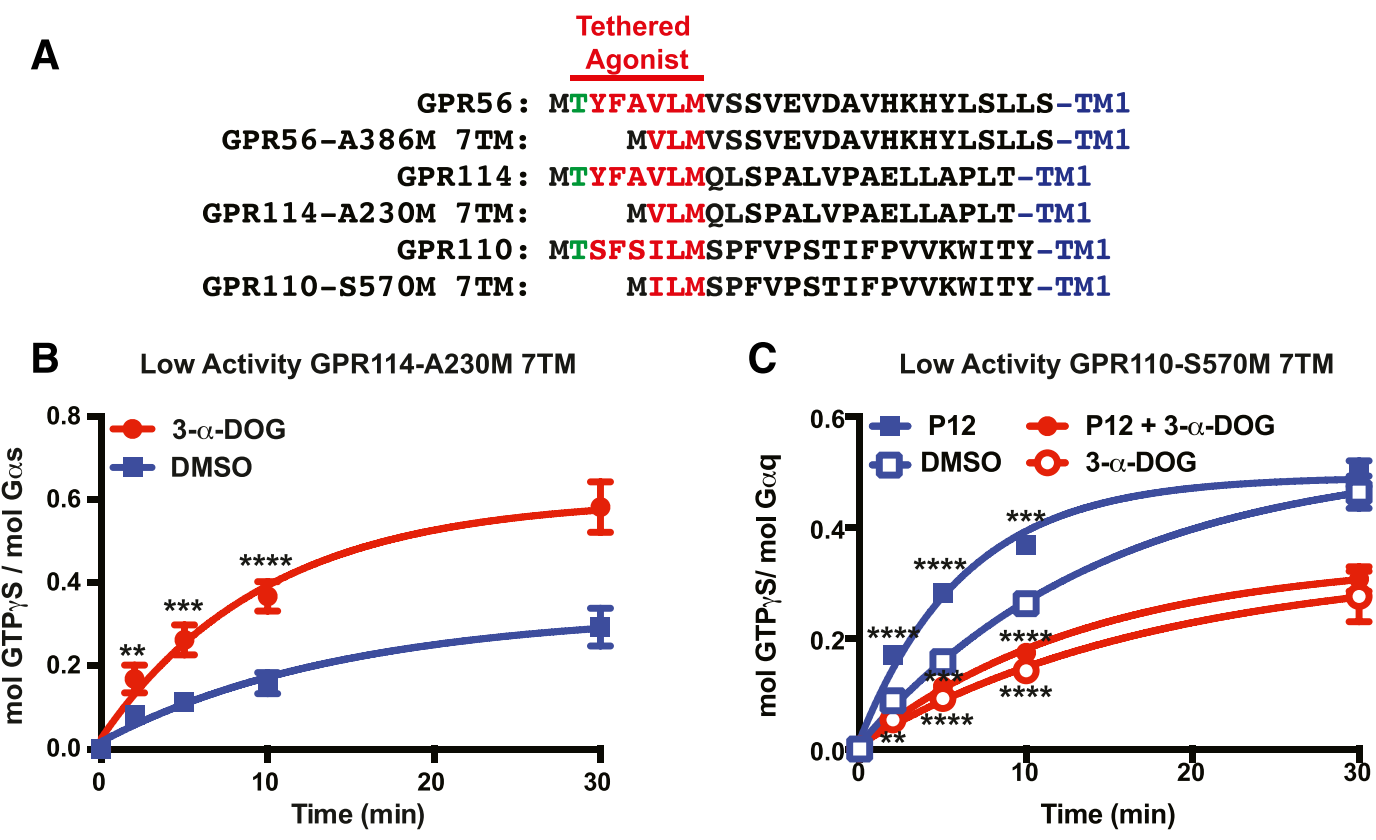

D

ß2 Adrenergic Receptor

E M3 Muscarinic Acetylcholine Receptor
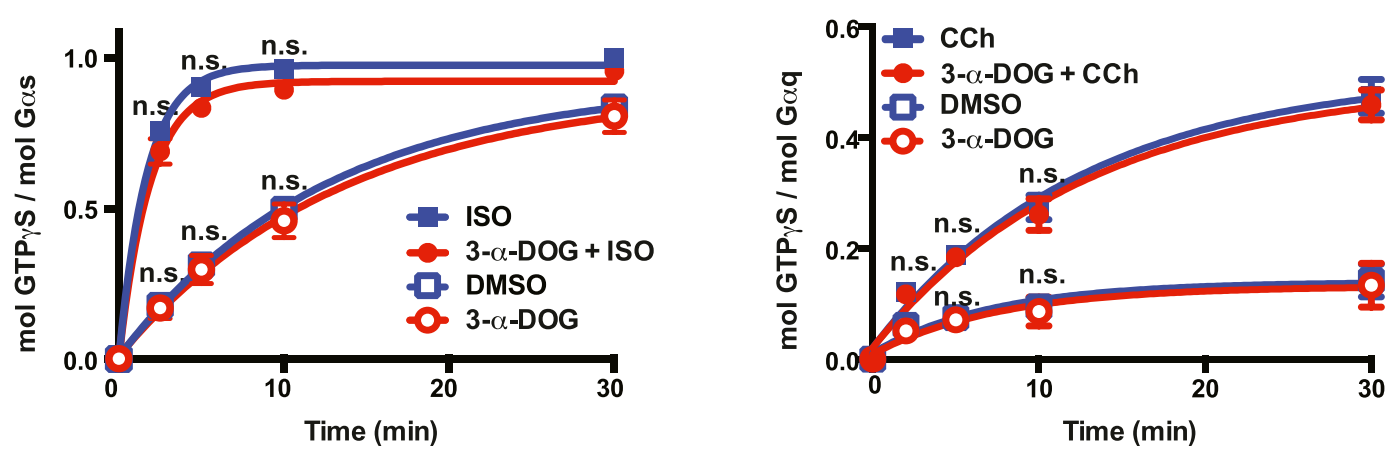

Fig. 3. 3- $\alpha$-Acetoxydihydrodeoxygedunin GPCR specificity. (A) Schematic of the full and truncated tethered-agonist regions of GPR56/ADGRG1, GPR114/ADGRG5, and GPR110/ADGRF1 receptors. The kinetics of G protein activation were measured in the presence of 0 or $20 \mu \mathrm{M} 3-\alpha-\mathrm{DOG}$ for (B) GPR114-A230M 7TM and Gs, (C) GPR110-S570M 7TM and Gq, stimulated with or without synthetic peptide agonist (P12, TSFSILMSPFVP), (D) $\beta 2$ adrenergic receptor ( $\beta 2 \mathrm{AR}$ ) and Gs with vehicle or $10 \mu \mathrm{M}$ isoproterenol (ISO), and (E) M3 muscarinic acetylcholine receptor (M3R) and Gq with vehicle or $50 \mu \mathrm{M}$ carbachol. The data were fitted to one-phase monoexponential association functions using GraphPad Prism. Error bars are the mean \pm S.D. of three experimental replicates with two to three technical replicates per experiment $(* * P<0.01 ; * * * P<0.001 ; * * * *<0.0001$; n.s., not significant compared with cells treated with DMSO).

A386M or GPR56-H401M 7TM receptors. The membranes were reconstituted with purified $\mathrm{G} \alpha 13$ and $\mathrm{G} \beta_{1} \gamma_{2}$ (Fig. 2D). 3 - $\alpha$-DOG greatly augmented the kinetics of GPR56-A386Mmediated G13 activation and, to a lesser degree, GPR56 H401M-mediated G13 activation. 3- $\alpha$-DOG did not activate G13 GTP $\gamma$ S binding in the presence of naïve membranes. As this biochemical assay is completely distinct from the cellbased screening assay used to initially identify $3-\alpha$-DOG, the results validate $3-\alpha$-DOG as a GPR56-activating compound.

An independent cell-based assay was then used to measure the acute effects of 3- $\alpha$-DOG-mediated receptor activation. G12/13-stimulated RhoA-GTP accumulation was measured by GST-rhotekin pulldown assay in HEK293T cells transiently transfected with GPR56-A386M 7TM and HA-tagged RhoA (Paavola et al., 2011; Stoveken et al., 2016). Rho-GTP levels were elevated within the first 2 minutes after treatment of cell culture medium with $5 \mu \mathrm{M} 3-\alpha$-DOG (Fig. $2 \mathrm{E}$ ). Low detectable levels of Rho-GTP were found in the DMSO/vehicle-treated control cells. Application of synthetic peptide agonist P7
(20 $\mu \mathrm{M}, 10$ minutes) also elevated Rho-GTP levels in accordance with our previous results (Stoveken et al., 2016) (Fig. 2E). $3-\alpha$-DOG was then tested for activation of full-length GPR56 in which the noncovalently bound NTF was left intact or was chemically dissociated from the 7TM domain by urea treatment to reveal the tethered-peptide-agonist. 3- $\alpha$-DOG $(20 \mu \mathrm{M})$ did not activate either receptor but provided modest inhibition (Fig. $2 \mathrm{~F})$. These results suggest that 3- $\alpha$-DOG may interfere with the action of the intact GPR56 tethered-peptide agonist.

3- $\alpha$-DOG GPCR Specificity. Two additional truncated tethered-peptide-agonist adhesion GPCRs were used to test the specificity of $3-\alpha$-DOG. GPR114/ADGRG5 belongs to the same adhesion GPCR subfamily (group VIII) as GPR56 and the receptors share perfect sequence identity in the first seven amino acids of $\mathrm{N}$-terminal tethered-peptide-agonist stalk (TYFAVLM...) (Fig. 3A). GPR114 elevated cellular cAMP levels and was later found to couple directly to Gs in response to its tethered-peptide-agonist (Stoveken et al., 2016; Wilde et al., 2016). GPR110/ADGRF1 is one of five members of the 
adhesion GPCR group VI subfamily (Nordstrom et al., 2009). The N-terminus of its tethered-peptide-agonist shares 57\% identity with GPR56 or GPR114 (TYFAVLM vs. TSFSILM, Fig. 3A). GPR110 provided elevation of cellular cAMP levels in response to class VI aGPCR synthetic peptide agonists (Demberg et al., 2017). A second study purported that a docosahexaenoic acid metabolite, synaptamide, bound and activated GPR110 to elevate cAMP levels independently of GPR110 self-cleavage or tethered-peptide-agonism (Lee et al., 2016). GPR110 did not activate Gs in receptor reconstitution assays but avidly stimulated $\mathrm{Gq}$ with peptide-agonist dependence (Stoveken et al., 2015). Moreover, synaptamide has no ability to regulate GPR110-stimulated Gq or provide any gain of Gs function activation in this direct biochemical system (Supplemental Fig. 2).

3- $\alpha$-DOG activated the truncated tethered-peptide-agonist GPR114-A230M 7TM in the Gs reconstitution assay (Fig. 3B). However, 3- $\alpha$-DOG significantly inhibited the basal activity and synthetic peptide agonist (TSFSILMSPFVP-NH ${ }_{2}$ )-stimulated activity of the compromised tethered-peptide-agonist GPR110-S570M 7TM receptor (Fig. 3C). If 3- $\alpha$-DOG binds to adhesion GPCR orthosteric sites, then its capacity to activate GPR56 and GPR114 could be explained by the receptors having highly similar orthosteric sites that physiologically bind identical tethered-peptide-agonist sequences. Indeed, GPR114 synthetic peptide agonists were found to activate GPR56, and the only commonality of the synthetic peptide sequences between the two receptors are the first seven amino acids, TYFAVLM (Supplemental Fig. 3). GPR110 is activated by a peptide-agonist sequence structured in a similar way, albeit distinct. We propose that $3-\alpha-\mathrm{DOG}$ may bind the GPR110 orthosteric site in a nonproductive manner that inhibits receptor activity.

Additional GPCR and G protein specificity experiments were conducted to test the observed actions of $3-\alpha$-DOG. Two class A GPCRs, the $\beta 2$ adrenergic receptor ( $\beta 2 \mathrm{AR})$ and the M3 muscarinic acetylcholine receptor (M3R), were chosen because they couple to the same $\mathrm{G}$ proteins, Gs and Gq, as GPR114 and GPR110, respectively. Stimulation of the $\beta 2 \mathrm{AR}$ with $10 \mu \mathrm{M}$ isoproterenol (ISO) characteristically increased reconstituted Gs activation, but neither ISO-stimulated nor the high basal $\beta 2 \mathrm{AR}$ activities were modulated by $3-\alpha-\mathrm{DOG}$ (Fig. 3D). Similarly, 3- $\alpha$-DOG was tested with the Gq-coupled M3R with or without $50 \mu \mathrm{M}$ carbachol (Fig. $3 \mathrm{E}$ ). $3-\alpha$-DOG had no effect on synthetic hormone-stimulated or basal activity of the M3R. Overall, these results confirm that $3-\alpha-\mathrm{DOG}$ specifically activates adhesion GPCRs GPR56 and GPR114, at the same time excluding the possibility that the compound affected $G$ proteins in the reconstitution assays.

3- $\alpha$-DOG is a GPR56 Partial Agonist. If $3-\alpha$-DOG activates GPR56 as an orthosteric agonist, it would compete with other orthosteric modulatory compounds and syntheticor tethered-peptide-agonists. We recently described dihydromunduletone (DHM) as a GPR56/114 antagonist through demonstration that DHM blocked the actions of GPR56 synthetic- and tethered-peptide-agonists (Stoveken et al., 2016). DHM was classified as a near neutral antagonist because it did not inhibit the GPR56-A386M 7TM receptor, which, owing to its compromised tethered-peptide-agonist, is an approximate model of receptor basal activity (Fig. 4A) (Stoveken et al., 2016). When DHM was combined with $3-\alpha-$ DOG in the GPR56-A386M 7TM assay, the G13 activation

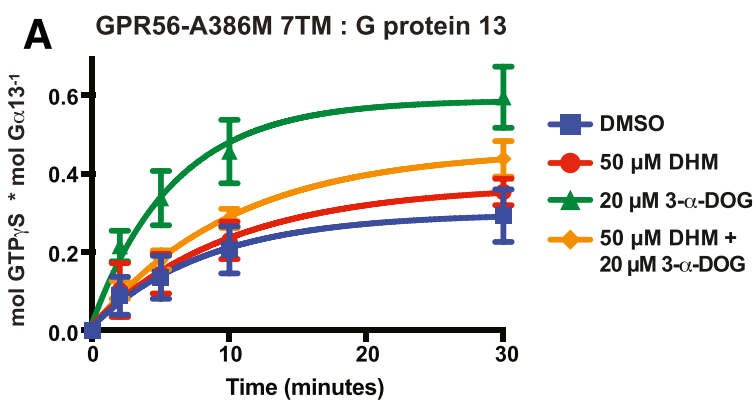

B GPR56-A386M 7TM : G protein 13

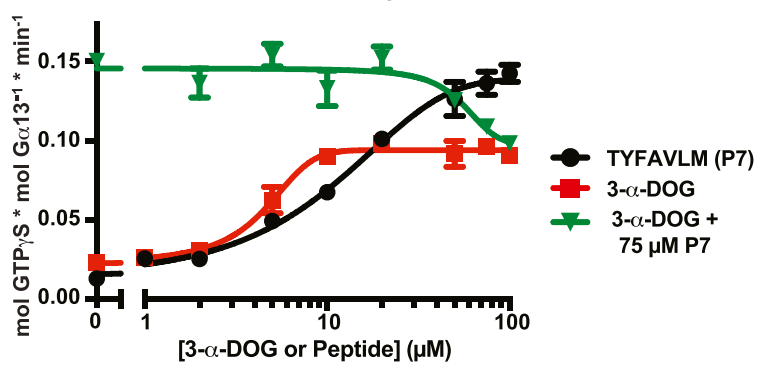

C

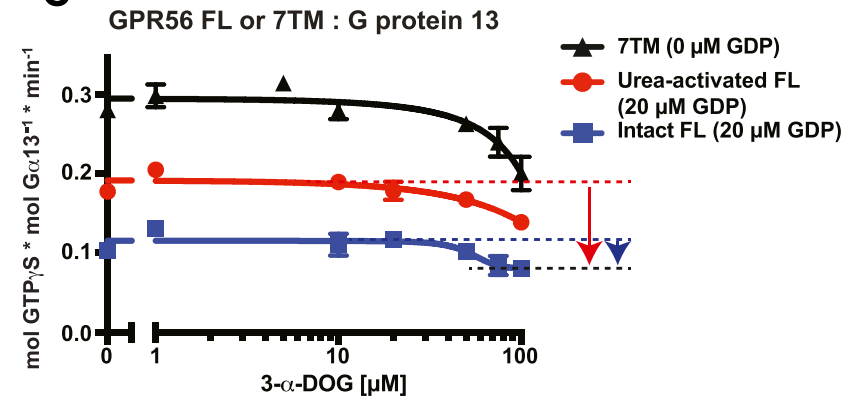

Fig. 4. $3-\alpha$-DOG is a partial agonist. (A) The kinetics of GPR56-A386M 7TM-stimulated G13 GTP $\gamma \mathrm{S}$ binding were measured in the presence of 3 - $\alpha$-DOG, the GPR56 GPCR antagonist, DHM, or both compounds. Error bars are the mean of three to four independent experiments with two to three technical replicates per experiment. Statistical analysis of the 2-, 5-, and 10-minute time points indicated from the 3- $\alpha$-DOG-treated receptor was significantly different $(P<0.01)$ than DMSO-treated receptor. For $3-\alpha$-DOG and DHM-treated receptor, at 2 minutes, $P<0.01$, and at 5 and 10 minutes $P<0.05$, compared with $3-\alpha$-DOG-treated receptor. No significant difference was observed between DMSO-treated and DHMtreated receptor. (B) The initial linear rates of GPR56-A386M 7TMstimulated G13 GTP $\gamma$ S binding were measured in the presence of the indicated concentrations of P7 synthetic agonist peptide, $3-\alpha$-DOG, or $3-\alpha-$ DOG with a fixed $\mathrm{EC}_{100}$ concentration $(75 \mu \mathrm{M})$ of P7. (C) GPR56 7TM (full tethered agonist) or full-length GPR56 kept intact or urea-activated were reconstituted with G13 and treated with increasing concentrations of 3- $\alpha$ DOG. The initial activation rates were plotted as a function of $3-\alpha$-DOG concentration. For initial rate experiments (B and C), error bars are mean \pm S.D. of the activation rates of three technical replicates.

kinetics were significantly reduced $(P<0.01)$ in comparison with those observed when $3-\alpha$-DOG was used alone to stimulate the receptor (Fig. 4A). This demonstrates that 3- $\alpha$ DOG opposes the action of the DHM antagonist and suggests that these two modulatory compounds may be competitive.

The concentration dependence and efficacy of $3-\alpha$-DOG receptor activation were compared with the GPR56 synthetic peptide agonist P7 (TYFAVLM-NH 2 ). 3- $\alpha$-DOG activated 
GPR56-A386M 7TM with an $\mathrm{EC}_{50}$ of $4.8 \pm 0.5 \mu \mathrm{M}$, which was more potent than P7 $(12.1 \pm 1.5 \mu \mathrm{M})$ (Fig. $4 \mathrm{~B})$. However, the maximal efficacy of receptor stimulation by $3-\alpha$-DOG (G13 GTP $\gamma \mathrm{S}$ binding rate of 0.10 minutes $^{-1}$ ) was substantially lower than that achieved with high concentrations of P7 (G13 GTP $\gamma \mathrm{S}$ binding rate of 0.14 minutes $^{-1}$ ). These data indicate that $3-\alpha-D O G$ is a partial agonist because submaximal efficacy of receptor activity plateaued with increasing concentrations of compound. As a partial agonist, 3- $\alpha$-DOG should antagonize the action of the higher efficacy P7 peptide agonist. $3-\alpha-\mathrm{DOG}$ concentration-response measurements were made in the presence of a P7 concentration that exhibited maximal efficacy (75 $\mu \mathrm{M}$ peptide). $3-\alpha$-DOG inhibited the $\mathrm{P} 7$ response in a concentration-dependent manner, and ultimately governed the maximal response efficacy (Fig. 4B). The 3- $\alpha$-DOG and 3- $\alpha$ DOG plus $75 \mu \mathrm{M}$ P7 response curves appeared to merge at the 3- $\alpha$-DOG-induced maximal efficacy; however, a full analysis using concentrations of $3-\alpha-\mathrm{DOG}$ or $\mathrm{P} 7>100 \mu \mathrm{M}$ was preempted owing to solubility issues of the compound and peptide.

At relatively low $3-\alpha$-DOG concentrations (5-20 $\mu \mathrm{M}), 3-\alpha-$ DOG did not interfere with GPR56 7TM tethered-agonistactivated SRE-luciferase activity or receptor-reconstituted G13 activation (Fig. 2, C and F). Therefore, we tested 3- $\alpha$ DOG-mediated inhibition of the preferred tethered agonist using GPR56 7TM and full-length GPR56 that was kept intact or activated by urea-mediated ECD dissociation (Fig. 4C). Initial G13 activation rates were plotted as a function of 3- $\alpha$ DOG concentration. The substantially lower activation rate of urea-activated GPR56 compared with GPR56 7TM was attributed to inclusion of $20 \mu \mathrm{M}$ GDP in the full-length GPR56 assays, as it is needed to reduce background signal from endogenous $G$ proteins present in the intact GPR56 membrane preparation. At higher concentrations that approached 3- $\alpha$-DOG maximal solubility $(\sim 100 \mu \mathrm{M})$, all three receptors were inhibited (Fig. $4 \mathrm{C}$ ). An inhibition plateau was approached for intact GPR56, but it could not be ascertained from the data whether the two higher activity receptors might plateau. A complete analysis of the maximal inhibitory efficacy of $3-\alpha$-DOG was prevented by the compound's insolubility at high concentrations.

Structure-Activity Relationship Analysis of 3- $\alpha$-DOGRelated Gedunin and Khivorin Compounds. The chemical structure of $3-\alpha$-DOG was examined to identify similar compounds in the Spectrum Collection with potential activity toward GPR56. Eight structurally related khivorin- and gedunin-derived compounds were selected as possible candidates (Akisanya et al., 1966). Purchased compounds were solubilized in DMSO from powder and added into the medium of GPR56-A386M 7TM-expressing HEK293T cells at $10 \mu \mathrm{M}$ 6 hours prior to measurement of SRE-luciferase activity. 3- $\alpha$ DOG stimulated the receptor response equally as well as $10 \mu \mathrm{M}$ P7 synthetic peptide agonist (Fig. 5A). Khivorin and 1,2-epoxygedunin activated the response to lesser degrees, but no significant activation was observed for the other five indicated gedunin or khivorin derivatives.

Detailed concentration-response curves for each of the eight compounds were then attained using the GPR56-A386M $7 \mathrm{TM} / \mathrm{G} 13$ reconstitution assay (Fig. $5 \mathrm{~B}$ ). The potency of each compound $\left(\mathrm{EC}_{50}\right)$ was determined by measuring the initial rates of GPR56-A386M 7TM-stimulated G13 activation and plotting each rate versus compound concentration. $3-\alpha-\mathrm{DOG}$ was the most potent compound with an $\mathrm{EC}_{50}$ of $4.8 \pm 0.5 \mu \mathrm{M}$, followed by khivorin with an $\mathrm{EC}_{50}$ of $7.2 \pm 2.4 \mu \mathrm{M}$ (Fig. 5, B and C). Both compounds were more potent than P7 synthetic peptide agonist, though less efficacious. 3-deacetylkhivorin and deoxygedunin were $\sim 6$ and $\sim 9$-fold less potent activators, respectively, than 3- $\alpha$-DOG. 1,2-Epoxygedunin had marginal activity in the receptor/G protein reconstitution assay, and the other tested compounds, 7-deacetoxy-7-oxokhivorin, 7-deacetoxy7-oxogedunin, and 1,7-dideacetoxy-1,7-dioxo-3-deacetylkhivorin did not activate GPR56. Interestingly, all of the compounds that exhibited activity in the GPR56/G13 reconstitution assay reached a partial agonist maximal efficacy that was $\sim 67 \%$ of the maximal efficacy of the $\mathrm{P} 7$ peptide (Fig. 5B). The few instances of variability that were observed between the cell-based SRE-luciferase assay and the receptor/G protein reconstitution assay could be attributed to differential solubility/bioavailability in cell culture medium versus GPCR reconstitution assay buffer.

Analysis of the structures of the individual compounds in comparison with the rank order of receptor-activation potency and efficacy permitted analysis of the structure-activity relationship. There are three carbon atoms within the tested gedunin and khivorin four-membered core ring structures that had prominent R-group substitutions: carbons 1, 3, and 7 (C1, C3, C7) (Fig. 5C). The $\mathrm{C} 1$ position had a variety of R-group substitutions, and no general activity trend related to substitution differences at $\mathrm{C} 1$ could be ascertained. The C7 position was most critical for activity, as the first five ranked compounds with any activity toward GPR56 activation had an acetoxy group at the position. The compounds that lacked a $\mathrm{C} 7$ acetoxy group (7-deacetoxy-7-oxokhivorin, 7-deacetoxy-7oxogedunin, and 1,7-dideacetoxy-1,7-dioxo-3-deacetylkhivorin) were entirely unable to activate the receptor (Fig. 5C). With an acetoxy group present at C7, a second acetoxy group at the C3 position dictated the highly potent activity of both $3-\alpha-\mathrm{DOG}$ and khivorin. 3-Deacetylkhivorin and deoxygedunin possess an hydroxyl or carbonyl group at the C3 position, respectively, and had reduced potency, but efficacies similar to $3-\alpha-D O G$ and khivorin.

\section{Discussion}

Understanding of the fundamental architecture of selfcleaved adhesion GPCRs and the mechanism of signaling to $\mathrm{G}$ proteins has advanced in recent years through solution of aGPCR extracellular-region structures and by delineation of the aGPCR tethered-peptide-agonist activation mechanism (Arac et al., 2012; Liebscher et al., 2014; Jackson et al., 2015; Lu et al., 2015; Stoveken et al., 2015). Identification and characterization of the diverse protein ligands that bind modules within aGPCR extracellular regions have also contributed to current models that predict physiologic aGPCR activation mechanisms (Hamann et al., 1996; Stacey et al., 2003; Vallon and Essler, 2006; Xu et al., 2006; Bolliger et al., 2011; Luo et al., 2011; Silva et al., 2011; O'Sullivan et al., 2012; Paavola et al., 2014; Stephenson et al., 2014; Petersen et al., 2015). A current challenge is to understand the physiologic means of aGPCR activation by tethered-peptide-agonists. We support a model of aGPCR activation that involves multiple steps:

1. Heterophilic, multivalent interactions between ECMor trans-cell protein-ligands with the adhesion modules 


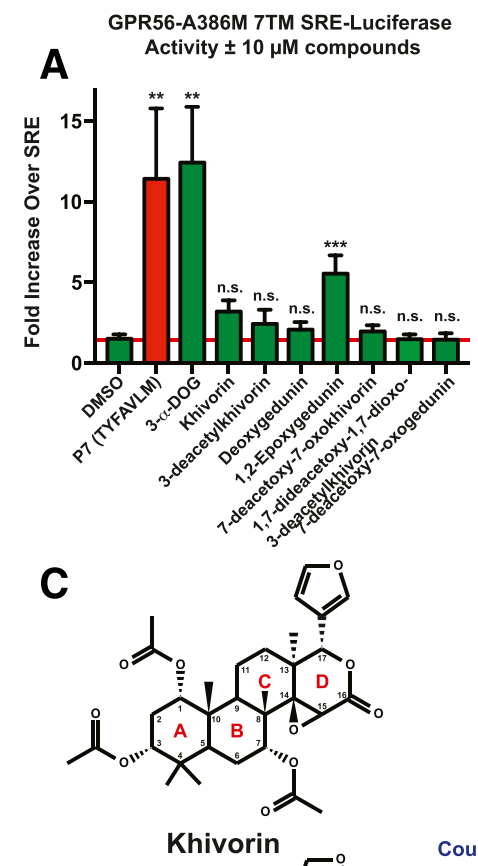

B
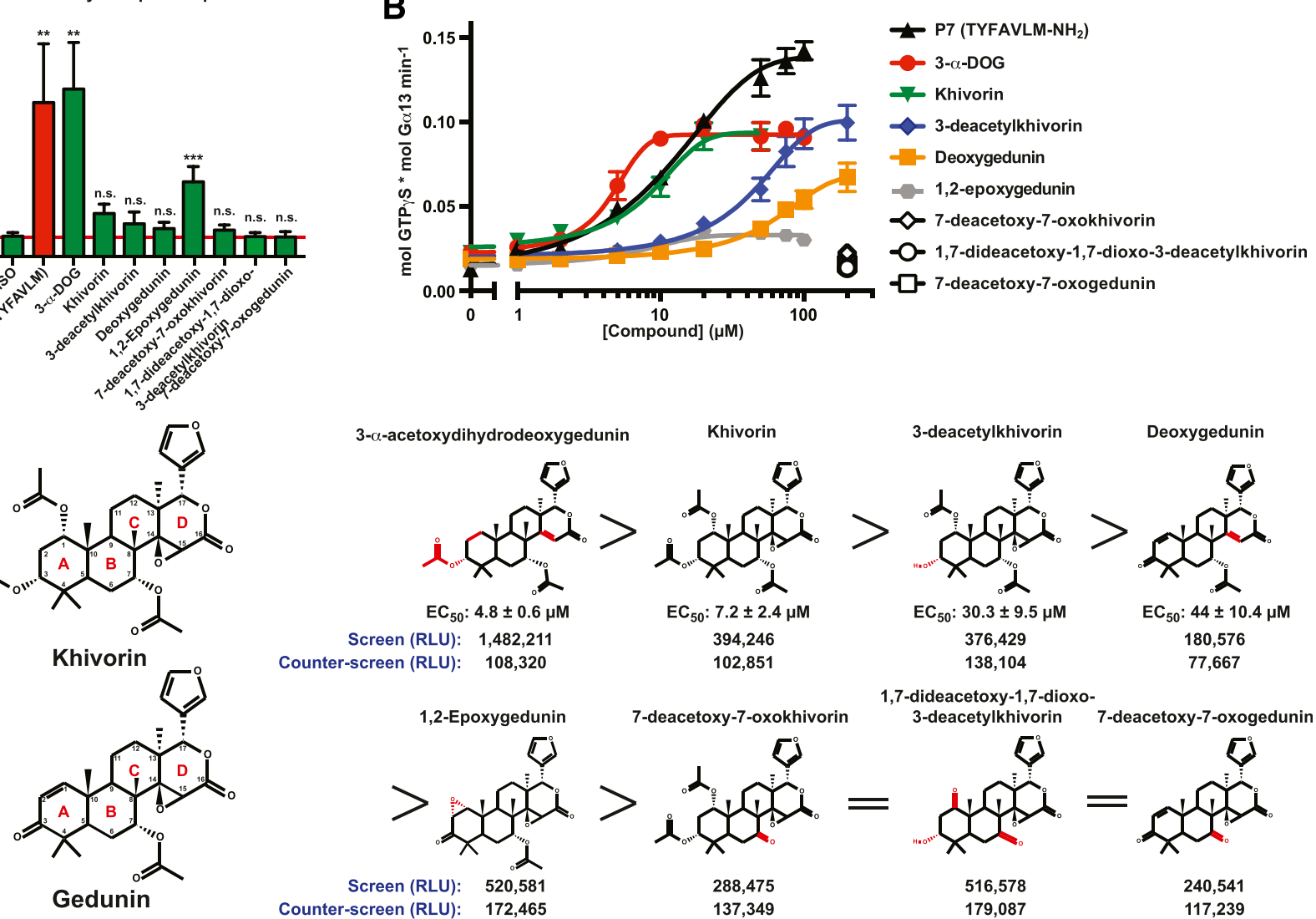

$1,7-$ dideacetoxy-1,7-dioxo-

3-deacetylkhivorin 7-deacetoxy-7-oxogedunin

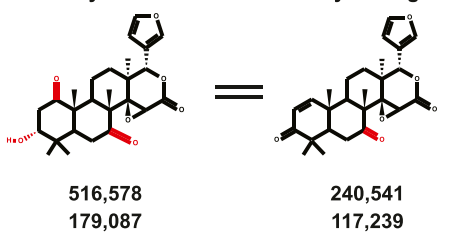

Fig. 5. Structure-activity relationship analysis of gedunin- and khivorin-derived natural products. (A) GPR56-A386M 7TM with indicated compounds in $10 \mu \mathrm{M}$ concentration activated SRE-luciferase to varying degrees. Data are the mean of four individual experiments with two-three technical replicates per condition \pm S.D. $(* * P<0.01 ; * * * P \leq 0.001 ; \mathrm{n}$.s., not significant compared with cells treated with DMSO). (B) The initial linear rates of GPR56-A386M 7TM-stimulated G13 GTP $\gamma$ S binding were measured in the presence of the indicated concentrations of individual compounds or P7 synthetic peptide agonist. The potency $\left(\mathrm{EC}_{50}\right)$ of each compound was estimated from semi-log plots of one-phase monoexponential functions generated using GraphPad Prism. Error bars are the mean \pm S.D. of three experimental replicates. (C) The chemical structures of khivorin and gedunin parent compounds are presented with the carbon atom numbering scheme. Capital letters refer to each of the four aromatic rings. The structures of the khivorin and gedunin derivatives are presented alongside the potency rankings attained from the G13 GTP $\gamma \mathrm{S}$ binding experiment and the raw values $(n=1)$ from the highthroughput screen and counter-screen of GPR56-A386M 7TM. Red coloring indicates locations where the compounds differ from the parent compound (gedunin or khivorin).

of aGPCR extracellular regions serving to anchor the aGPCR NTFs.

2. Movement of the aGPCR-expressing cell in relation to the anchor creates shear force sufficient to dissociate the noncovalently bound NTF and GPCR domain.

3 . This releases the extremely hydrophobic tetheredpeptide-agonist from the interior of the GAIN domain, which would be expected to reside fleetingly in the aqueous extracellular space prior to binding its orthosteric site within the GPCR domain.

There are alternative models of aGPCR activation in which mechanical stimulation or binding of protein ligands, small molecules, or engineered antibodies to the NTF influences GPCR domain signaling without apparent holo-receptor fragment dissociation, and/or in receptor cleavage-deficient models (Kishore et al., 2016; Lee et al., 2016; Salzman et al., 2017; Scholz et al., 2017). Given the concealment of the tetheredpeptide-agonists inside the cores of holo-receptor GAIN domains, these signaling modes would seem to be agonistindependent and may reflect subtler allosteric activation of basal receptor activities. Holo-receptor dissociation may be requisite for true orthosteric agonism. Part of the reason for the controversy in resolving different modes of aGPCR activation is the extreme challenge faced in designing experiments that could measure the three prospective steps of the holo-receptor dissociation/agonism model. Our use of urea to dissociate aGPCR NTFs from GPCR domains in membrane preparations, which led to greatly enhanced $\mathrm{G}$ protein activation kinetics, provides foundational evidence for the model, but urea treatment is merely a bypass of the combined steps of protein ligand anchoring and physiologic shear forces thought to induce holo-receptor dissociation leading to tetheredpeptide-agonist exposure (Karpus et al., 2013; Stoveken et al., 2015).

A straightforward way to investigate aGPCR activation mechanisms could be through the discovery and use of chemical probes that directly modulate receptor activities. Our cell-based high-throughput screen was designed to attain small molecules that activated an engineered, basally active GPR56 receptor. The top hit was the natural product, $3-\alpha-$ acetoxydihydrodeoxygedunin (3- $\alpha$-DOG), which was originally isolated from Azadirachta indica (i.e., the Indian Neem 
tree). $3-\alpha$-DOG belongs to a group of bioactive compounds termed limonoids that have been used as traditional herbal remedies to treat acne, skin disease, and many other afflictions (Brahmachari, 2004). Further research has suggested that Neem extracts exhibit antitumorigenic and antimalarial properties (Khalid et al., 1989; MacKinnon et al., 1997; Nagini, 2014). The parental compound, gedunin, was reported to ameliorate allergic inflammation, inhibit HSP90, and to be a prospective diabetes therapy as a pancreatic $\alpha$ amylase inhibitor (Hieronymus et al., 2006; Ferraris et al., 2012; Ponnusamy et al., 2015). Gedunins and structurally related khivorins may have multiple molecular targets but, encouragingly, Neem tree extracts and/or enriched compound mixtures have been found to be generally safe for human use and may be viable options for therapeutic development (Biswas et al., 2002).

The mode of action of the 3- $\alpha$-DOG gedunin/khivorin scaffold is consistent with that of an orthosteric binding site partial agonist. $3-\alpha-\mathrm{DOG}$ activated engineered GPCR domain receptors in which three or more amino-terminal residues of the tethered-peptide-agonist were absent. There was no activation of full-length receptors or GPCR domain receptors with intact tethered-peptide-agonists and, in fact, we observed modest inhibition of both at high $3-\alpha$-DOG concentrations. 3 - $\alpha$-DOG also partially inhibited the action of synthetic peptide agonist to achieve partial efficacy (Fig. 4B). Our interpretation is that $3-\alpha$-DOG occupies the orthosteric binding pocket to stabilize a partially active receptor conformation. As GPCR domain-only receptors are fully activated owing to first-order binding of the intact tethered-peptide-agonist, $3-\alpha$ DOG partial inhibition is explainable if $3-\alpha$-DOG competes with the (full) tethered-peptide-agonist to ultimately dictate a partial agonist-activated state (Fig. 4B). Membrane preparations with full-length aGPCRs probably consist of holoreceptors and a population of GPCR domains from which the NTF has dissociated. The orthosteric binding sites of the dissociated receptor population are expected to be occupied by tethered-peptide-agonists. Therefore, observed activity from a full-length aGPCR membrane preparation is contributed by basal activities plus the tethered-peptide-agonist-stimulated activity of the GPCR domain population (Stoveken et al., 2016). 3- $\alpha$-DOG partial inhibition of the full-length GPR56 preparation is explained if the dominant contributing activity is the tethered-agonist-activated population. A priori, $3-\alpha-$ DOG would be expected to partially activate the holo-receptor population. However, this was not observed, a finding that is consistent with our previous observations that synthetic peptide agonists did not activate holo-receptors either, perhaps owing to occlusion or inverse agonism of the nondissociated NTF (Stoveken et al., 2015).

Our immediate plans include further examination of 3- $\alpha$-DOG specificity toward additional aGPCRs as a prelude to using 3- $\alpha$ DOG as a tool compound to learn about functional and structural features of aGPCR orthosteric binding pockets. Thus far, 3- $\alpha$ DOG did not affect two class A GPCRs, but it did activate GPR56 and GPR114, at the same time inhibiting GPR110. aGPCR tethered-peptide-agonists are very hydrophobic and share significant sequence conservation. This suggests that the orthosteric binding pockets of the receptor class have similar architectures, with subtle differences that may typify subgroups of receptors. The N-terminal seven amino acids (TYFAVLM) of the GPR56 and GPR114 tethered-peptide-agonist stalks are identical and both receptors are activated by long, 18- to 20-residue GPR114 synthetic agonist stalk peptides, even though the GPR114 peptide sequence completely diverges from GPR56 sequence after the first seven residues (Supplemental Fig. 3) (Wilde et al., 2016). Because the GPR110 tetheredpeptide-agonist sequence TSFSILM differs from the GPR56/114 sequence, the observed 3- $\alpha$-DOG inhibition of GPR110 suggests that the compound may access the GPR110 orthosteric site but does so in a manner that inhibits the receptor, rather than acting as a partial agonist. Use of $3-\alpha-D O G$ as an aGPCR probe compound may also help define modes of aGPCR physiologic activation and permit evaluation of the effects of aGPCR disease mutations on receptor signaling.

One hurdle to overcome prior to expanded use of aGPCR modulatory compounds or synthetic agonist peptides in organismal studies is the relatively low potency of these activating ligands. Synthetic-peptide-agonists and the available modulatory compounds to date activate aGPCRs at high micromolarto-millimolar concentrations. This aligns with the natural condition; peptide agonists are tethered and therefore, high affinity binding to the orthosteric site may not be required due the very high effective concentration of the agonist (Liebscher et al., 2014; Stoveken et al., 2015; Wilde et al., 2016). To develop aGPCR modulatory compounds as tenable therapeutic leads that target aGPCRs in vivo, higher affinity must be achieved. The fact that 3- $\alpha$-DOG activates GPR56 with greater potency $(\sim 5 \mu \mathrm{M})$ than the synthetic peptide agonist $(\sim 12.1 \mu \mathrm{M})$, holds promise that small molecules can be developed that are more potent and specific than larger synthetic-peptide-agonists. Our structure-activity relationship analysis showed that the $3-\alpha$ DOG/gedunin backbone presents numerous opportunities for chemical substitution at various points in its four-ring backbone structure. We explored substitutions found in natural product derivatives primarily at the 1-, 3-, and 7- carbon positions and found that the identity of the R-group attached to the $\mathrm{C} 7$ position was most critical for activity (Fig. 5). Natural alterations of groups attached to the $\mathrm{C} 3$ position influenced the potency of GPR56 activation. Continued efforts to test additional natural product derivatives of $3-\alpha-\mathrm{DOG}$ and to perform chemical modifications at the critical positions will be needed to improve potency of the 3- $\alpha$-DOG/gedunin scaffold as a highaffinity GPR56/114 probe compound.

We envision another potential use of $3-\alpha-\mathrm{DOG}$ as a tool compound for GPR56 or GPR114 functional studies that has parallels to DREAD/RASSL technologies, or more aptly to "neoceptor" strategies (Strader et al., 1991; Coward et al., 1998; Armbruster et al., 2007; Jacobson et al., 2007). Our engineered GPR56/114 receptors may be excellent candidates to act as engineered neoceptors because they will not respond to endogenous ligands, as the NTFs are not present, and they possess low basal activity owing to the absence of intact tethered-peptide-agonists. $3-\alpha$-DOG could act as a probe compound that would selectively activate GPR56 or GPR114 neoceptors to elicit biologic function in a tissue targeted for selective neoceptor expression.

\section{Authorship Contributions}

Participated in research design: Stoveken, Smrcka, Tall. Conducted experiments: Stoveken, Tall.

Performed data analysis: Stoveken, Larsen, Tall. Tall. 


\section{References}

Akisanya A, Arene EO, Bevan CWL, Ekong DEU, Nwaji MN, Okogun JI, Powell JW, and Taylor DAH (1966) West African timbers. 12. inter-relation of gedunin and khivorin. J Chem Soc C:506-509.

Araç D, Boucard AA, Bolliger MF, Nguyen J, Soltis SM, Sudhof TC, and Brunger AT (2012) A novel evolutionarily conserved domain of cell-adhesion GPCRs mediates autoproteolysis. EMBO J 31:1364-1378.

Armbruster BN, Li X, Pausch MH, Herlitze S, and Roth BL (2007) Evolving the lock to fit the key to create a family of $\mathrm{G}$ protein-coupled receptors potently activated by an inert ligand. Proc Natl Acad Sci USA 104:5163-5168.

Aust G (2010) Adhesion-GPCRS in tumorigenesis. Adv Exp Med Biol 706:109-120.

Aust G, Zhu D, Van Meir EG, and Xu L (2016) Adhesion GPCRs in tumorigenesis. Handb Exp Pharmacol 234:369-396.

Biswas K, Chattapadhyay I, Banerjee RK, and Bandyopadhyay U (2002) Biological activities and medicinal properties of neem (Azadirachta indica). Curr Sci $\mathbf{8 2}$ 1336-1345.

Bolliger MF, Martinelli DC, and Sudhof TC (2011) The cell-adhesion G proteincoupled receptor BAI3 is a high-affinity receptor for C1q-like proteins. Proc Natl Acad Sci USA 108:2534-2539.

Brahmachari G (2004) Neem-an omnipotent plant: a retrospection. ChemBioChem $\mathbf{5}$ 408-421.

Bridges JP, Ludwig MG, Mueller M, Kinzel B, Sato A, Xu Y, Whitsett JA, and Ikegami M (2013) Orphan G protein-coupled receptor GPR116 regulates pulmonary surfactant pool size. Am J Respir Cell Mol Biol 49:348-357.

Chan P, Gabay M, Wright FA, Kan W, Oner SS, Lanier SM, Smrcka AV, Blumer JB and Tall GG (2011) Purification of heterotrimeric G protein alpha subunits by GSTRic-8 association: primary characterization of purified $\mathrm{G}$ alpha(olf). $J$ Biol Chem 286:2625-2635.

Coward P, Wada HG, Falk MS, Chan SD, Meng F, Akil H, and Conklin BR (1998) Controlling signaling with a specifically designed Gi-coupled receptor. Proc Natl Acad Sci USA 95:352-357.

de Groot DM, Vogel G, Dulos J, Teeuwen L, Stebbins K, Hamann J, Owens BM, van Eenennaam H, Bos E, and Boots AM (2009) Therapeutic antibody targeting of CD97 in experimental arthritis: the role of antigen expression, shedding, and in ternalization on the pharmacokinetics of anti-CD97 monoclonal antibody 1B2. $J$ Immunol 183:4127-4134.

Demberg LM, Winkler J, Wilde C, Simon KU, Schon J, Rothemund S, Schoneberg T, Promel S, and Liebscher I (2017) Activation of adhesion G protein-coupled receptors: agonist specificity of Stachel sequence-derived peptides. J Biol Chem 292: 4383-4394.

Dyer BW, Ferrer FA, Klinedinst DK, and Rodriguez R (2000) A noncommercial dual luciferase enzyme assay system for reporter gene analysis. Anal Biochem 282: $158-161$.

Ferraris FK, Moret KH, Figueiredo AB, Penido C, and Henriques M (2012) Gedunin, a natural tetranortriterpenoid, modulates $\mathrm{T}$ lymphocyte responses and ameliorates allergic inflammation. Int Immunopharmacol 14:82-93.

Gupte J, Swaminath G, Danao J, Tian H, Li Y, and Wu X (2012) Signaling property study of adhesion G-protein-coupled receptors. FEBS Lett 586:1214-1219.

Hamann J, Aust G, Arac D, Engel FB, Formstone C, Fredriksson R, Hall RA, Harty BL, Kirchhoff C, Knapp B, et al. (2015) International union of basic and clinical pharmacology. XCIV. adhesion G protein-coupled receptors. Pharmacol Rev 67: 338-367.

Hamann J, Vogel B, van Schijndel GM, and van Lier RA (1996) The seven-span transmembrane receptor CD97 has a cellular ligand (CD55, DAF). J Exp Med 184 $1185-1189$

Hieronymus H, Lamb J, Ross KN, Peng XP, Clement C, Rodina A, Nieto M, Du J, Stegmaier K, Raj SM, et al. (2006) Gene expression signature-based chemical genomic prediction identifies a novel class of HSP90 pathway modulators. Cancer Cell 10:321-330.

Iguchi T, Sakata K, Yoshizaki K, Tago K, Mizuno N, and Itoh H (2008) Orphan G protein-coupled receptor GPR56 regulates neural progenitor cell migration via a G alpha 12/13 and Rho pathway. J Biol Chem 283:14469-14478.

Jackson VA, del Toro D, Carrasquero M, Roversi P, Harlos K, Klein R, and Seiradake E (2015) Structural basis of latrophilin-FLRT interaction. Structure 23:774-781.

Jacobson KA, Gao ZG, and Liang BT (2007) Neoceptors: reengineering GPCRs to recognize tailored ligands. Trends Pharmacol Sci 28:111-116.

Kamath SG, Chen N, Xiong Y, Wenham R, Apte S, Humphrey M, Cragun J, and Lancaster JM (2009) Gedunin, a novel natural substance, inhibits ovarian cancer cell proliferation. Int $J$ Gynecol Cancer 19:1564-1569.

Karpus ON, Veninga H, Hoek RM, Flierman D, van Buul JD, Vandenakker CC, vanBavel E, Medof ME, van Lier RA, Reedquist KA, et al. (2013) Shear stressdependent downregulation of the adhesion-G protein-coupled receptor CD97 on circulating leukocytes upon contact with its ligand CD55. J Immunol 190: 3740-3748.

Khalid SA, Duddeck H, and Gonzalez-Sierra M (1989) Isolation and characterization of an antimalarial agent of the neem tree Azadirachta indica. J Nat Prod 52 922-926.

Kishore A, Purcell RH, Nassiri-Toosi Z, and Hall RA (2016) Stalk-dependent and stalk-independent signaling by the adhesion $\mathrm{G}$ protein-coupled receptors GPR56 (ADGRG1) and BAI1 (ADGRB1). J Biol Chem 291:3385-3394.

Kozasa T and Gilman AG (1995) Purification of recombinant G proteins from Sf9 cells by hexahistidine tagging of associated subunits. Characterization of alpha 12 and inhibition of adenylyl cyclase by alpha z. J Biol Chem 270:1734-1741.

Laemmli UK (1970) Cleavage of structural proteins during the assembly of the head of bacteriophage T4. Nature 227:680-685.

Langenhan T, Aust G, and Hamann J (2013) Sticky signaling-adhesion class G protein-coupled receptors take the stage. Sci Signal 6:re3.
Lee JW, Huang BX, Kwon H, Rashid MA, Kharebava G, Desai A, Patnaik S, Marugan J, and Kim HY (2016) Orphan GPR110 (ADGRF1) targeted by N-docosahexaenoylethanolamine in development of neurons and cognitive function. Nat Commun 7:13123.

Liebscher I, Schon J, Petersen SC, Fischer L, Auerbach N, Demberg LM, Mogha A, Coster M, Simon KU, Rothemund S, et al. (2014) A tethered agonist within the ectodomain activates the adhesion $\mathrm{G}$ protein-coupled receptors GPR126 and GPR133. Cell Reports 9:2018-2026.

Lin HH, Chang GW, Davies JQ, Stacey M, Harris J, and Gordon S (2004) Autocatalytic cleavage of the EMR2 receptor occurs at a conserved G protein-coupled receptor proteolytic site motif. $J$ Biol Chem 279:31823-31832.

Lu YC, Nazarko OV, Sando R, III, Salzman GS, Sudhof TC, and Arac D (2015) Structural basis of latrophilin-FLRT-UNC5 interaction in cell adhesion. Structure 23:1678-1691.

Luo R, Jeong SJ, Jin Z, Strokes N, Li S, and Piao X (2011) G protein-coupled receptor 56 and collagen III, a receptor-ligand pair, regulates cortical development and lamination. Proc Natl Acad Sci USA 108:12925-12930.

MacKinnon S, Durst T, Arnason JT, Angerhofer C, Pezzuto J, Sanchez-Vindas PE, Poveda LJ, and Gbeassor M (1997) Antimalarial activity of tropical Meliaceae extracts and gedunin derivatives. $J$ Nat Prod 60:336-341.

Nagini S (2014) Neem limonoids as anticancer agents: modulation of cancer hallmarks and oncogenic signaling, in Enzymes: Natural Products and Cancer Signaling: Isoprenoids, Polyphenols and Flavonoids (Machinda Y, Lin C, and Tamanoi F eds) pp 131-147. Elsevier, New York.

Nordström KJ, Lagerstrom MC, Waller LM, Fredriksson R, and Schioth HB (2009) The secretin GPCRs descended from the family of adhesion GPCRs. Mol Biol Evol 26:71-84

O’Hayre M, Vazquez-Prado J, Kufareva I, Stawiski EW, Handel TM, Seshagiri S, and Gutkind JS (2013) The emerging mutational landscape of G proteins and G-protein-coupled receptors in cancer. Nat Rev Cancer 13:412-424.

Oner SS, Blumer JB, and Lanier SM (2013) Group II activators of G-protein signaling: monitoring the interaction of Galpha with the G-protein regulatory motif in the intact cell. Methods Enzymol 522:153-167.

O'Sullivan ML, de Wit J, Savas JN, Comoletti D, Otto-Hitt S, Yates JR, III, and Ghosh A (2012) FLRT proteins are endogenous latrophilin ligands and regulate excitatory synapse development. Neuron 73:903-910.

Paavola KJ, Sidik H, Zuchero JB, Eckart M, and Talbot WS (2014) Type IV collagen is an activating ligand for the adhesion G protein-coupled receptor GPR126. Sci Signal 7:ra76.

Paavola KJ, Stephenson JR, Ritter SL, Alter SP, and Hall RA (2011) The N terminus of the adhesion $\mathrm{G}$ protein-coupled receptor GPR56 controls receptor signaling activity. J Biol Chem 286:28914-28921.

Petersen SC, Luo R, Liebscher I, Giera S, Jeong SJ, Mogha A, Ghidinelli M, Feltri ML, Schoneberg T, Piao X, et al. (2015) The adhesion GPCR GPR126 has distinct, domain-dependent functions in Schwann cell development mediated by interaction with laminin-211. Neuron 85:755-769.

Ponnusamy S, Haldar S, Mulani F, Zinjarde S, Thulasiram H, and RaviKumar A (2015) Gedunin and Azadiradione: human pancreatic alpha-amylase inhibiting limonoids from neem (Azadirachta indica) as anti-diabetic agents. PLoS One 10 e0140113.

Roy A and Saraf S (2006) Limonoids: overview of significant bioactive triterpenes distributed in plants kingdom. Biol Pharm Bull 29:191-201.

Salzman GS, Zhang S, Gupta A, Koide A, Koide S, and Arac D (2017) Stachelindependent modulation of GPR56/ADGRG1 signaling by synthetic ligands directed to its extracellular region. Proc Natl Acad Sci USA 114: 10095-10100.

Schaffner W and Weissmann C (1973) A rapid, sensitive, and specific method for the determination of protein in dilute solution. Anal Biochem 56:502-514.

Scholz N, Gehring J, Guan C, Ljaschenko D, Fischer R, Lakshmanan V, Kittel RJ, and Langenhan T (2015) The adhesion GPCR latrophilin/CIRL shapes mechanosensation. Cell Rep 11:866-874.

Scholz N, Guan C, Nieberler M, Grotemeyer A, Maiellaro I, Gao S, Beck S, Pawlak M, Sauer M, Asan E, et al. (2017) Mechano-dependent signaling by Latrophilin/CIRL quenches cAMP in proprioceptive neurons. eLife 6:e28360 DOI: 10.7554/ eLife.28360

Silva JP, Lelianova VG, Ermolyuk YS, Vysokov N, Hitchen PG, Berninghausen O, Rahman MA, Zangrandi A, Fidalgo S, Tonevitsky AG, et al. (2011) Latrophilin 1 and its endogenous ligand Lasso/teneurin-2 form a high-affinity transsynaptic receptor pair with signaling capabilities. Proc Natl Acad Sci USA 108 $12113-12118$.

Southern C, Cook JM, Neetoo-Isseljee Z, Taylor DL, Kettleborough CA, Merritt A Bassoni DL, Raab WJ, Quinn E, Wehrman TS, et al. (2013) Screening beta-arrestin recruitment for the identification of natural ligands for orphan G-protein-coupled receptors. J Biomol Screen 18:599-609.

Stacey M, Chang GW, Davies JQ, Kwakkenbos MJ, Sanderson RD, Hamann J, Gordon S, and Lin HH (2003) The epidermal growth factor-like domains of the human EMR2 receptor mediate cell attachment through chondroitin sulfate glycosaminoglycans. Blood 102:2916-2924.

Stephenson JR, Purcell RH, and Hall RA (2014) The BAI subfamily of adhesion GPCRs: synaptic regulation and beyond. Trends Pharmacol Sci 35: 208-215.

Stoveken HM, Bahr LL, Anders MW, Wojtovich AP, Smrcka AV, and Tall GG (2016) Dihydromunduletone is a small-molecule selective adhesion G protein-coupled receptor antagonist. Mol Pharmacol 90:214-224.

Stoveken HM, Hajduczok AG, Xu L, and Tall GG (2015) Adhesion G protein-coupled receptors are activated by exposure of a cryptic tethered agonist. Proc Natl Acad Sci USA 112:6194-6199.

Strader CD, Gaffney T, Sugg EE, Candelore MR, Keys R, Patchett AA, and Dixon RA (1991) Allele-specific activation of genetically engineered receptors. J Biol Chem 266:5-8. 
Uddin SJ, Nahar L, Shilpi JA, Shoeb M, Borkowski T, Gibbons S, Middleton M, Byres M, and Sarker SD (2007) Gedunin, a limonoid from Xylocarpus granatum, inhibits the growth of $\mathrm{CaCo}-2$ colon cancer cell line in vitro. Phytotherapy research. PTR 21: 757-761.

Vallon M and Essler M (2006) Proteolytically processed soluble tumor endothelial marker (TEM) 5 mediates endothelial cell survival during angiogenesis by linking integrin alpha(v)beta3 to glycosaminoglycans. J Biol Chem 281: 34179-34188

Veninga H, Becker S, Hoek RM, Wobus M, Wandel E, van der Kaa J, van der Valk M, de Vos AF, Haase H, Owens B, et al. (2008) Analysis of CD97 expression and manipulation: antibody treatment but not gene targeting curtails granulocyte migration. J Immunol 181:6574-6583.

Wilde C, Fischer L, Lede V, Kirchberger J, Rothemund S, Schoneberg T, and Liebscher I (2016) The constitutive activity of the adhesion GPCR GPR114/ADGRG5 is mediated by its tethered agonist. FASEB $J$ 30:666-673.
Xu L, Begum S, Hearn JD, and Hynes RO (2006) GPR56, an atypical G proteincoupled receptor, binds tissue transglutaminase, TG2, and inhibits melanoma tumor growth and metastasis. Proc Natl Acad Sci USA 103:9023-9028.

Yona S, Lin HH, Dri P, Davies JQ, Hayhoe RP, Lewis SM, Heinsbroek SE, Brown KA, Perretti M, Hamann J, et al. (2008a) Ligation of the adhesion-GPCR EMR2 regulates human neutrophil function. FASEB $J$ 22:741-751.

Yona S, Lin HH, Siu WO, Gordon S, and Stacey M (2008b) Adhesion-GPCRs: emerging roles for novel receptors. Trends Biochem Sci 33:491-500.

Zhang JH, Chung TD, and Oldenburg KR (1999) A simple statistical parameter for use in evaluation and validation of high throughput screening assays. J Biomol Screen 4:67-73.

Address correspondence to: Dr. Gregory G. Tall, Department of Pharmacology, University of Michigan, MSRBIII Room 1220A, Ann Arbor, MI 481095632. E-mail: gregtall@med.umich.edu 